\title{
Pengaruh pendidikan virtual pencegahan COVID-19 terhadap pengetahuan guru sekolah berbasis boarding school di Kabupaten Garut
}

\section{The effect of virtual education of COVID-19 prevention on knowledge of boarding school teacher based in Garut district}

\author{
Sitti Syabariyah ${ }^{1 *}$, Retno Anesti ${ }^{2}$, Wika Puspika Sari ${ }^{3}$ \\ 1,2,3 Program Studi Sarjana Keperawatan Sekolah Tinggi Ilmu Kesehatan ‘Aisyiyah Bandung, 40264, Indonesia \\ ${ }^{1}$ sittisyabariyah@gmail.com*; ${ }^{2}$ retnoanesti@gmail.com; ${ }^{3}$ wikap1904@gmail.com; \\ *corresponding author
}

Tanggal Submisi: 1 Juni 2021, Tanggal Penerimaan: 12 Juli 2021

\begin{abstract}
Abstrak
Upaya pemerintah dalam mewaspadai risiko lebih besar dan penyebarannya, maka saat ini perlu meningkatkan kesadaran dan pengetahuan sekolah terutama guru yang dapat berperan sebagai pintu masuk pendidikan secara optimal tentang pencegahan penyebaran COVID-19 terutama bagi siswa dan orang tua siswa (masyarakat) yang lebih luas. Tujuan penelitian ini untuk mengetahui efektifitas media audiovisual dalam edukasi pendidikan kesehatan pencegahan COVID-19 terhadap peningkatan pengetahuan guru-guru di SMP Islam berbasis boarding school. Desain penelitian merupakan penelitian kuasi eksperimen dengan pendekatan one group pretest-post test. Guru diberikan kuesioner tentang COVID-19 dan pencegahannya di lingkungan sekolah kemudian guru diberikan edukasi melalui media audiovisual selama 7 menit dan diminta kembali mengisi kuesioner yang sama dengan sebelumnya. Hasil penelitian menunjukan bahwa pengetahuan responden secara keseluruhan sebelum perlakuan terbagi menjadi $41,67 \%$ baik, 50\% cukup dan 8,33\% kurang, setelah perlakuan data menunjukan $100 \%$ pengetahuan responden menjadi baik. Dengan demikian dapat disimpulkan H0 ditolak dan Ha diterima atau hipotesis penelitian diterima.
\end{abstract}

Kata kunci: pencegahan penyebaran COVID-19, pengetahuan guru

\begin{abstract}
The government's efforts to be aware of the greater risk and its spread, so now it is necessary to increase awareness and knowledge of schools, especially teachers who can play a role as the entrance to education in an optimal way on preventing the spread of COVID-19, especially for students and parents of students (the wider community). The purpose of this study was to determine the effectiveness of audiovisual media in health education education for the prevention of COVID-19 towards increasing the knowledge of teachers in Islamic Junior High Schools based on boarding schools. The research design was a quasi-experimental study with a one group pretest-posttest approach. The teacher was given a questionnaire about covid-19 and its prevention in the school environment, then the teacher was given education through audiovisual media for 7 minutes and asked to complete the same questionnaire as before. The results showed that the respondents 'knowledge as a whole before the treatment was divided into $41.67 \%$ good, $50 \%$ sufficient and $8.33 \%$ less, after treatment the data showed that $100 \%$ of the respondents' knowledge was good. Thus it can be concluded that $\mathrm{HO}$ is rejected and $\mathrm{Ha}$ is accepted or the research hypothesis is accepted.
\end{abstract}


Keywords: prevention of the spread of COVID-19, teacher knowledge

\section{PENDAHULUAN}

WHO mengumumkan Corona Virus Disease-19 (COVID-19) sebagai pandemik. Data terbaru sampai dengan tanggal 25 September 2020, kasus Global Covid-19 terdapat 32.110.656 kasus konfirmasi, 980.031 kematian (CFR 3,05\%) 215 negara terjangkit, 195 negara transmisi lokal (WHO, 2020). COVID-19 pertama dilaporkan di Indonesia pada tanggal 2 Maret 2020 sejumlah dua kasus. Data 6 September 2020 menunjukan di Indonesia kasus terkonfirmasi positif Covid-19 berjumlah 266.845 (4.823 kasus baru) (Kemenkes, 2020) Di Jawa Barat data tanggal 26 September 2020 menunjukan kasus terkonfirmasi positif Covid-19 berjumlah 20.131. Jawa Barat juga pernah menjadi provinsi dengan jumlah kasus tertinggi yakni dengan penambahan kasus sebanyak 965 dalam waktu sehari pada tanggal 9 Juli 2020 (pikobar.jabarprov.go.id, 2020). Masih tingginya angka pasien positif, PDP, dan ODP Covid19 di seluruh Indonesia, dan juga beberapa wilayah di Jawa Barat, khususnya di daerah Kabupaten Garut dan sekitarnya, mengindikasikan bahwa penularan virus corona ini masih terus berlangsung (Puspasari, 2020). Untuk itu diperlukan tambahan sosialisasi dan edukasi tentang cara pencegahan virus corona ini secara sederhana terhadap masyarakat. Juga diperlukan sosialisai dan edukasi kepada masyarakat khususnya guru-guru sekolah tentang bagaimana menjadi garda terdepan memberikan pemahaman untuk meminimasi dan memutus mata rantai penyebaran virus corona ini (Hirooka, 2020).

Masa darurat COVID-19 yang mengharuskan semua guru dan siswa belajar dari rumah nyatanya tak sekadar mengubah lokasi dan metode belajar. Lebih besar dari itu, COVID-19 telah mendorong banyak pihak melakukan perubahan dalam dunia dan pendidikan di Indonesia hanya dalam hitungan bulan (Salzberger et al, 2020). Kementerian Pendidikan dan Kebudayaan (Kemendikbud) telah melakukan berbagai penyesuaian pembelajaran selama masa pandemi. Salah satunya mendorong guru untuk tidak fokus mengejar target kurikulum semata selama masa darurat, melainkan juga membekali siswa akan kemampuan hidup yang sarat dengan nilai-nilai penguatan karakter, pembelajaran tentang perilaku hidup sehat dan bersih (PSB) tentang pencegahan penyebaran COVID-19 terutama jika sekolah-sekolah nantinya akan kembali mengadakan tatap muka (Suni, 2020).

Pemerintah RI beberapa waktu yang lalu telah mengumumkan Penyesuaian Keputusan Bersama Empat Menteri tentang Panduan Pembelajaran di Masa Pandemi COVID-19. Hal ini mempertimbangkan kebutuhan pembelajaran, berbagai masukan dari para ahli dan organisasi serta mempertimbangkan evaluasi implementasi SKB Empat Menteri terkait pelaksanaan pembelajaran di zona selain merah dan oranye, yakni di zona kuning dan hijau, untuk dapat melaksanakan pembelajaran tatap muka dengan penerapan protokol kesehatan yang sangat ketat. "Prioritas utama pemerintah adalah untuk mengutamakan kesehatan dan keselamatan peserta didik, pendidik, tenaga kependidikan, keluarga, dan masyarakat secara umum, serta mempertimbangkan tumbuh kembang peserta didik dan kondisi psikososial dalam upaya pemenuhan layanan pendidikan selama pandemi COVID-19. Mendikbud mengatakan kondisi Pandemi COVID-19 tidak memungkinkan kegiatan belajar mengajar berlangsung secara normal. Terdapat ratusan ribu sekolah ditutup untuk mencegah penyebaran, sekitar 68 juta 
siswa melakukan kegiatan belajar dari rumah, dan sekitar empat juta guru melakukan kegiatan mengajar jarak jauh (Tim Kerja Kementerian Dalam Negeri, 2020).

Tahapan pembelajaran tatap muka satuan pendidikan di zona hijau dan zona kuning dalam SKB Empat Menteri yang disesuaikan tersebut dilakukan secara bersamaan pada jenjang pendidikan dasar dan menengah dengan pertimbangan risiko kesehatan yang tidak berbeda untuk kelompok umur pada jenjang lainnya (Kemenkes, 2020). Madrasah dan sekolah berasrama di zona hijau dan zona kuning dapat membuka asrama dan melakukan pembelajaran tatap muka secara bertahap sejak masa transisi. Kapasitas asrama dengan jumlah peserta didik kurang dari atau sama dengan 100 orang pada masa transisi bulan pertama adalah 50 persen, bulan kedua 100 persen, kemudian terus dilanjutkan 100 persen pada masa kebiasaan baru. Untuk kapasitas asrama dengan jumlah peserta didik lebih dari 100 orang, pada masa transisi bulan pertama 25 persen, dan bulan kedua 50 persen, kemudian memasuki masa kebiasaan baru pada bulan ketiga 75 persen, dan bulan keempat 100 persen (Ega, 2020).

Kemunculan pandemik COVID-19 telah merubah hampir seluruh sistem tatanan kehidupan manusia. Organisasi Kesehatan dunia (WHO) secara resmi menyatakan bahwa COVID-19 menjadi pandemik global dan meminta ke semua negara terutama masyarakat dunia untuk melakukan upaya maksimal guna pencegahan, pembatasan penyebaran maupun jumlah kasus COVID-19. Hal ini juga berlaku secara nasional dan regional dimana pemerintah pusat dan daerah mendorong pemberdayaan masyarakat termasuk sektor Pendidikan dalam pencegahan COVID-19 melalui upaya yang dilakukan oleh seluruh komponen dengan menggali potensi yang dimiliki agar berdaya dan mampu berperan serta mencegah penularan covid-19 ini. Jawa Barat merupakan salah satu provinsi yang terdampak penyebaran covid 19. Hal ini sejalan dengan berkembangnya wabah COVID-19 di dunia, hingga ke sejumlah wilayah di Indonesia. Hal ini tentu sangat mengkhawatirkan seluruh lapisan masyarakat, termasuk penyebarannya telah ditemukan di Kabupaten Garut. Untuk mewaspadai risiko lebih besar dan penyebarannya, maka saat ini perlu upaya meningkatkan kesadaran dan pengetahuan sekolah terutama guru yang dapat berperan sebagai pintu masuk pendidikan secara optimal tentang pencegahan penyebaran COVID-19 terutama bagi siswa dan orang tua siswa (masyarakat) yang lebih luas. Jika guru memiliki pengetahuan yang benar, maka guru dapat menjadi change agent upaya-upaya promotif kesehatan sekaligus preventif. Pemberian edukasi dalam pencegahan penyebaran COVID-19 dapat didukung oleh media edukasi yang baik dan mudah dimengerti oleh guru.

Hal diatas tentu saja perlu kesiapan pihak sekolah untuk memahami bagaimana melakukan upaya-upaya khusunya bidang kesehatan dan fasilitas yang perlu dan wajib disediakan agar sekolah benar-benar layak untuk dibuka kembali. Hal terpenting lainnya adalah membangun kesadaran guru, siswa, orang tua dan masyarakat akan pengenalan tentang bahaya, penyebaran dan pencegahan yang dapat dilakukan jika masa adaptasi kebiasaan baru dan sekolah dibuka kembali (Shereen et al, 2020). Guru sebagai garda terdepan yang dapat menjadi role model yang benar bagi siswa dan masyarakat (orang tua) perlu dibekali dengan pengetahuan yang tepat terlebih dahulu agar sekolah mampu membuat aturan dan perilaku yang diharapkan dari siswanya (Compton et al, 2020). Sekolah berasrama (boarding school) merupakan sekolah yang memiliki resiko tinggi kontak antar penghuninya yaitu siswa dan guru, karena siswa akan 24 jam berinteraksi satu dengan lainnya. Jika tidak dikondisikan 
dengan tata kelola yang baik, maka akan memiliki resiko penularan yang tinggi akan penyebaran COVID-19 ini (Covino et al., 2020).

Keberhasilan pemberian edukasi ditunjang oleh media edukasi yang baik. Media pendidikan kesehatan merupakan komponen yang sangat penting dalam penyampaian informasi karena memiliki kekuatan untuk menarik perhatian. Media yang menarik akan memberikan keyakinan, sehingga perubahan kognitif afeksi dan psikomotor dapat dipercepat. Media audiovisual adalah media penyampaian informasi yang memiliki karakteristik suara dan gambar. Jenis media ini mempunyai kemampuan yang lebih baik, karena meliputi kedua karakteristik tersebut sehingga penyampaian informasi menjadi lebih efektif (Lumbanbatu, 2018).

Sekolah Menengah Pertama (SMP) As-Syarief Islamic Boarding School dan SMP Al Masduqi Islamic Boarding School Garut ini merupakan dua institusi pendidikan berbasis boarding school yang memiliki program sekolah berasrama, dimana siswanya tinggal secara penuh di lingkungan sekolah. Kedua sekolah ini terletak di Kabupaten Garut. Salah satu sekolah terletak di daerah terpencil pegunungan ini jarang sekali tersentuh oleh sosialisasi pendidikan kesehatan dari Dinas Kesehatan Kabupaten apalagi Provinsi, sedangkan sekolah lainnya terletak di kota Garut yang mudah mendapatkan akses informasi dari pemerintah kabupaten. Namun ditemukan nilai positif pada proses pendidikan dan pembelajaran di lingkungan kedua SMP boarding school tersebut yang dapat menjadi potensi untuk memberdayakan guru-guru dan siswa/I nya karena adanya pengembangan Empat Pilar Pendidikan yaitu: sarana memahami pengetahuan (learning to know), bertindak kreatif sesuai lingkungan (learning to do), partisipasi dan kerja sama (learning to live together) serta pengembangan kepribadian dan tanggung jawab (learning to be) (Özdemir, 2020).

Berdasarkan data UKS dan laporan kesehatan siswa oleh Kepala Sekolah serta dinas pendidikan Kabupaten Garut yaitu bahwa pada bulan Agustus ini akan dilakukan masa transisi untuk memulai pembelajaran tatap muka langsung (luring) secara bertahap. Namun belum seluruh sekolah mendapatkan sosialisasi persiapan menghadapai masa transisi tersebut dari segi kesehatan. Oleh karena itu sangat dibutuhkan keikut sertaan berbagai elemen masyarakat termasuk Perguruan Tinggi untuk membantu memberikan pemahaman dan meningkatkan pengetahuan guru-guru sebagai garda terdepan pemberi informasi yang tepat bagi siswasiswanya agar memahami protokol kesehatan yang baik dan benar, sehingga sekolah terhindar menjadi tempat penyebaran COVID-19 ini. Tujuan penelitian ini untuk mengetahui efektifitas media audiovisual dalam edukasi pendidikan kesehatan pencegahan COVID-19 terhadap peningkatan pengetahuan guru-guru di SMP Islam berbasis boarding school.

\section{METODE PENELITIAN}

Penelitian ini adalah penelitian analitik komparatif dengan jenis pretest-posttest control group design. Untuk mencapai tujuan dan target yang diharapkan, Pada rancangan ini intervensi yang diberikan adalah tayangan video pendidikan kesehatan pencegahan penyebaran COVID-19. Populasi dalam penelitian ini adalah seluruh guru SMP di 2 SMP Islam berbasis boarding School di desa dan Kota Garut, yang diambil secara purposive sampling, dengan total populasi yaitu 48 orang guru. Instrumen yang digunakan dalam penelitian ini menggunakan google form quesionary yang dikembangkan oleh peneliti dan telah melalui uji validitas dan reliabilitas data. Dilakukan pada Guru SMK As Syarief Garut. 
Pengambilan data dilakukan pada bukan Juni 2020 meliputi semua guru SMP di SPM Islam As Syarief Boarding School dan SMP Islam Al Masduqi Boarding School. Adapun prosedur pelaksanaan : Peneliti dibantu oleh mahasiswa mendatangi Sekolah. Memberikan penjelasan terkait penelitian. Memberikan link pre-test sebanyak 20 pertanyaan, intervensi dan post-test sebanyak 20 pertanyaan yang dapat diisi dan disaksikan oleh responden. Peneliti memberikan informasi mengenai tujuan dan tindakan yang dilakukan selama penelitian dilaksanakan. Jika bersedia maka diminta untuk mengisi lembar Informed Consent melalui aplikasi Google Form; Sampel yang memenuhi kriteria diminta kesediaannya untuk menjadi responden. Responden kemudian diberi penjelasan secara rinci tentang prosedur penelitian, yaitu dengan menyaksikan pendidikan kesehatan melalui link yang telah diberikan; Responden menyaksikan tayangan (audiovisual) video melalui link tersebut, diberikan waktu untuk menginternalisasi; Setelah 1 jam, maka responden diberikan link post test melalui aplikasi google form.

\section{HASIL DAN PEMBAHASAN} bivariat.

Penelitian ini terbagi menjadi 2 tahap analisis, yaitu analisis univariat dan analisis

\section{Analisis Univariat}

Analisis univariat salah satunya digunakan untuk mengetahui distribusi frekuensi karakteristik responden, sebagaimana tersaji pada Tabel 1.

Tabel 1. Distribusi Frekuensi Karakteristik Responden (Usia Guru, Jenis Kelamin, Pendidikan Guru, Mata Ajar yang Diampu, Asal Sekolah dan Pengetahuan)

\begin{tabular}{lcc}
\hline \multicolumn{1}{c}{ Variabel } & n & \% \\
\hline Usia Guru & & \\
25-35 Tahun & 12 & 25 \\
35-45 Tahun & 29 & 60 \\
$>$ 45 tahun & 7 & 15 \\
Jumlah & 48 & 100 \\
\hline Jenis Kelamin & & \\
Laki- Laki & 17 & 35 \\
Perempuan & 31 & 65 \\
Jumlah & 48 & 100 \\
\hline Pendidikan Guru & & \\
S1 & 42 & 35 \\
S2 & 6 & 65 \\
Jumlah & 48 & 100 \\
\hline Mata Ajar yang Diampu & & \\
TIK & 2 & 4 \\
IPS & 4 & 8,33 \\
Tahsin/ Tahfids & 10 & 20,83 \\
Bahasa Inggris & 4 & 8,33 \\
Bahasa Sunda & 2 & 4 \\
Bahasa Arab & 5 & 10,41 \\
Matematika & 3 & 6,25 \\
IPA & 4 & 8,33 \\
BK & 4 & 8,33 \\
Kewarganegaraan & 3 & 6,25 \\
Keterampilan/ Seni/ & 7 & 14,6 \\
Ekskul & & \\
\hline
\end{tabular}


6

\begin{tabular}{lcc}
\hline Jumlah & 48 & 100 \\
\hline Asal Sekolah & & \\
SMP Islam As Syarief & 24 & 50 \\
SMP Islam Al Masduqi & 24 & 50 \\
Jumlah & & 100 \\
\hline Pengetahuan & 48 & \\
Baik & 10 & 40 \\
Cukup & 10 & 8 \\
Kurang & 28 & 0 \\
Jumlah & 48 & 100 \\
\hline
\end{tabular}

Tingkat pengetahuan responden dibagi menjadi 3 (tiga) kategori, yaitu kategori baik, cukup dan kurang. Pengetahuan yaitu suatu hasil dari rasa keingintahuan melalui proses sensoris, terutama pada mata dan telinga terhadap objek tertentu. Pengetahuan dipengaruhi oleh faktor pendidikan formal dan sangat erat hubungannya. Diharapkan dengan pendidikan yang tinggi maka akan semakin luas pengetahuannya. Gambaran pengetahuan sebelum dan sesudah diberikan perlakuan tersaji pada Tabel 2.

Tabel 2. Gambaran Tingkat Pengetahuan Berdasarkan Dimensi Upaya Pencegahan Penyebaran Covid -19 dan kesiapan Sekolah dalam melaksanakan New Normal Bulan Juni $2020(\mathrm{n}=48)$

\begin{tabular}{lcc}
\hline \multicolumn{1}{c}{ Pengetahuan } & Pretest & Postest \\
\hline Penggunaan Masker & & \\
Baik & $20(41,67 \%)$ & $48(100 \%)$ \\
Cukup & $24(50 \%)$ & $0(0 \%)$ \\
Kurang & $4(8,33 \%)$ & $0(0 \%)$ \\
\hline Mencuci Tangan dengan 6 Langkah Benar & & \\
Baik & $10(20,83 \%)$ & $48(100 \%)$ \\
Cukup & $10(20,83 \%)$ & $0(0 \%)$ \\
Kurang & $28(58,34 \%)$ & $0(0 \%)$ \\
\hline Physical Distancing & $15(31,25 \%)$ & \\
Baik & $20(41,67 \%)$ & $48(100 \%)$ \\
Cukup & $13(27,08) \%)$ & $0(0 \%)$ \\
Kurang & $10(20,83 \%)$ & $0(0 \%)$ \\
\hline Prosedur Disinfektan & $22(45,83 \%)$ & $48(100 \%)$ \\
Baik & $16(33,34 \%)$ & $0(0 \%)$ \\
Cukup & & $0(0 \%)$ \\
Kurang & $12(25 \%)$ & \\
\hline Prinsip Kebujakan Sekolah di Masa Pandemik & $28(58,34 \%)$ & $48(100 \%)$ \\
Baik & $8(16,67 \%)$ & $0(0 \%)$ \\
Cukup & & $0(0 \%)$ \\
Kurang & $15(31,25 \%)$ & \\
\hline PHBS & $25(52,08 \%)$ & $48(100 \%)$ \\
Baik & $8(16,67 \%)$ & $0(0 \%)$ \\
Cukup & & $0(0 \%)$ \\
Kurang & $20(41,67 \%)$ & $48(100 \%)$ \\
\hline Pengetahuan Total & $24(50 \%)$ & $0(0 \%)$ \\
Baik & $4(8,33 \%)$ & $0(0 \%)$ \\
Cukup & $D$ Purang & \\
\hline
\end{tabular}

Sumber : Hasil Pengolahan Data Primer, 2020

Tabel 2 menyajikan informasi tentang tingkat pengetahuan responden sebelum dan sesudah perlakuan yaitu pemberian edukasi dengan menggunakan media audiovisual. Pengetahuan responden tentang penggunaan masker, mencuci tangan dengan 6 langkah, 
physical distancing, prosedur disinfektan, prinsip kebijakan sekolah di masa pandemic/ new normal, PHBS terjadi peningkatan signifikan yang ditunjukkan dengan hasil post test mencapai $100 \%$ memahami ke tingkat pengetahuan baik.

\section{Analisis Bivariat}

Analisis bivariat digunakan untuk melihat pengaruh media audiovisual pencegahan penyebaran terhadap perubahan tingkat pengetahuan tentang pencegahan dan kesiapan sekolah dalam memasuki masa new normal (Tabel 3). Uji statistik yang digunakan untuk membuktikan hipotesis penelitian adalah uji Wilcoxon.

Tabel 3. Efektvitas Media Audiovisual terhadap Tingkat Pengetahuan Responden Guru dalam pencegahan penyebaran Covid-19 dan kesiapan sekolah dalam memasuki masa New Normal 2020 ( $\mathrm{n}=48)$

\begin{tabular}{lccc}
\hline \multicolumn{1}{c}{ Variabel } & $\begin{array}{c}\text { Rata-Rata } \\
\text { Sebelum }(\mathbf{\%})\end{array}$ & $\begin{array}{c}\text { Rata-Rata Setelah } \\
(\boldsymbol{\%})\end{array}$ & $\begin{array}{c}\text { Nilai } \\
\text { P }\end{array}$ \\
\hline Penggunaan Masker & $65,52 \pm 33,04$ & 100,0 & 0,000 \\
\hline Mencuci tangan dengan 6 langkah benar & $58,28 \pm 25,21$ & 100,0 & 0,000 \\
\hline Physical Distancing & $62,41 \pm 23,42$ & 100,0 & 0,000 \\
\hline Prosedur disinfektan & $50,48 \pm 18,75$ & 100,0 & 0,000 \\
\hline $\begin{array}{l}\text { Prinsip kebijakan Sekolah memasuki di masa pandemic } \\
\text { (new normal) }\end{array}$ & $51,38 \pm 20,56$ & 100,0 & 0,000 \\
\hline PHBS & $68,28 \pm 20,21$ & 100,0 & 0,000 \\
\hline Pengetahuan Total & $59,40 \pm 18,94$ & 100,0 & 0,000 \\
\hline
\end{tabular}

Sumber : Hasil Pengolahan Data Primer, 2020

Berdasarkan hasil perhitungan uji Wilcoxon menunjukkan bahwa nilai $\mathrm{p}=0,000$ $(<0,005)$ pada masing-masing dimensi pengetahuan dan pengetahuan secara total. Dengan demikian artinya media audiovisual tentang pencegahan penyebaran COVID-19 berpengaruh terhadap perubahan tingkat pengetahuan guru tentang upaya-upaya pencegahan penyebaran COVID-19 dan kesiapan sekolah dalam menghadapai new normal karena adanya peningkatan pengetahuan antara sebelum dan setelah diberikan perlakuan berupa edukasi dengan media audiovisual.

Pembahasan dari gambaran karakteristik responden menunjukan rata-rata usia responden guru SMP adalah usia 35-45 tahun. Jumlah pada usia tersebut sebanyak 29 orang. Hal ini sesuai dengan usia produktif seorang guru yang dapat dikatakan matang dalam pengalaman dan siap dalam memberikan pendidikan pada peserta didik.

Usia sesorang sangat mempengaruhi segala aspek kehidupan. Seorang guru yang mempunyai usia matang mampu menjalankan tugas nya dengan baik. Usia guru yang berpengaruh positif terhadap kegiatan belajar mengajar itu ada batasnya. Jadi terdapat titik dimana usia seorang guru berpengaruh negative. Usia juga mempengaruhi mental, aspek mental seseorang antara lain mengamati/pengamatan, mengingat/ingatan, imajinasi, kombinasi aktivitas psikis, abstraksi/pikiran, dan pemakaian tanda atau simbolis. Hasil penelitian ini sejalan dengan penelitian yang dilakukan oleh Budi (2015), dimana usia guru memiliki korelasi yang erat dengan kompetensi kepribadian.

Dengan kematangan usia maka seorang guru dapat menerima infornmasi berupa pengetahuan baru dengan rasionalisasi yang logis dan penuh tanggung jawab untuk 
mengimplementasikan informasi yang memang dapt memberikan kemanfaatan bagi orang lain dalam hal ini para siswanya. Peneliti mengeksplorasi lebih lanjut, bahwa dengan usia yang berada pada interval 35-45 tahun tersebut, guru sangat antusias mengikuti pendidikan virtual yang menambah pengetahuannya tentang pencegahan COVID-19, dan menyatakan akan segera menyebarkan informasi interaktif tersebut kepada siswa, karena memandang bahwa pendidikan itu sangat inovatif dan mudah dipahami. Lebih lanjut mereka menyatakan bahwa siswa SMP saat memiliki kecenderungan lebih mudah menerima pendidikan dan informative yang menarik melalui visual yaitu video dari pada sekedar penyampaian di kelas.

Selain usia yang menggambarkan korelasi dengan penerimaan informasi, yaitu latar belakang pendidikan. Notoatmodjo, (2014) mengungkapkan bahwa pengetahuan dipengaruhi oleh faktor internal yang meliputi pendidikan, semakin tinggi pendidikan seseorang tingkat pengetahuan juga semakin meningkat. Hasil penelitian menunjukan pendidikan rata-rata responden penelitian yang lulusan Perguruan tinggi yaitu strata sarjana (S1). Hal ini menunjukkan bahwa pendidikan yang tinggi memudahkan seseorang menerima informasi. Seseorang akan mudah menerima lebih banyak informasi sehingga tingkat pengetahuan menjadi lebih baik.

Dari enam elemen penilaian tentang pengetahuan, pencegahan penyebaran COVID-19 dan persiapan sekolah menghadapai masa transisi new normal, pengetahuan mayoritas responden tentang cara mencuci tangan yang benar dan prosedur disinfektan sebelum intervensi masih rendah. Peneliti berasumsi bahwa prosedur cuci tangan dan infektan belum pernah diberikan secara benar. Cuci tangan hanya diketahui dengan membilas tangan dengan gerakan yang tidak sistematis, dan menggunakan sabun. Prosedur cuci tangan bersih dengan enam langkah benar belum banyak diketahui orang awam termasuk responden. Oleh karenanya perlu pendidikan lebih lanjut berkaitan dengan cuci tangan benar.

Setelah pemberian pendidikan virtual berupa prosedur mencuci tangan bersih dan benar enam langkah dan prosedur disinfektan, pengetahuan guru meningkat dengan signifikan. Saat dilakukan redemonstrasi, guru-guru dapat menunjukkan cara mencuci tangan dengan tepat (100\%). Hal ini dilakukan peneliti pada evaluasi penelitian sebagai tindak lanjutnya.

Sementara pada analisis bivariat menunjukan adanya peningkatan signifikan tingkat pengetahuan responden (guru SMP Islam Berbasis Boarding School) terhadap pencegahan penyebaran COVID-19 di lingkungan sekolah dan kesiapan sekolah dalam rangka menghadapi persiapan pembelajaran pada masa new normal dengan media audiovisual video edukasi. Dengan demikian dapat disimpulkan bahwa H0 ditolak dan Ha diterima atau hipotesis penelitian diterima.

Hasil penelitian ini sejalan penelitian Lumbanbatu (2018) bahwa media audiovisual lebih efektif dalam memberikan pendidikan kesehatan terhadap pengetahuan dibandingkan dengan media non-audivisual. Konsisten dengan penelitian Karan, Abraar M. (2011) yang menyatakan bahwa alat bantu multimedia efektif dalam meningkatkan pemahaman responden bahkan untuk respondendengan pengetahuan yang terbatas.

Pada penelitian yang dilakukan oleh peneliti, pengetahuan responden tentang penggunaan masker, prosedur mencuci tangan, social distancing, prosedur disinfektan, 
kebijakan sekolah pada masa new normal dan prinsip PHBS setelah pendidikan berbasis virtual (audiovisual video) menunjukkan capaian yang sangat baik. Hasil penelitian berdasarkan pengisian kuesioner yang dilakukan sebelum pemberian perlakuan menunjukan pengetahuan responden yang masih kurang adalah tentang cara mencuci tangan dengan enam langkah benar dan prosedur disinfektan. Namun, setelah perlakuan didapatkan pengetahuan seluruh responden tentang kedua hal menjadi baik.

Menurut Notoatmodjo (2014) media atau alat peraga yang baik dapat dilihat, didengar, diraba, dirasa atau dicium untuk memperlancar komunikasi dan penyebar-luasan informasi. Media audiovisual sebagai media pendidikan kesehatan yang memiliki bentuk audio dan visual, menyampaikan lebih banyak informasi yang dapat ditangkap oleh indera manusia yaitu didengar oleh telinga dan dilihat melalui mata. Oleh karena itu, pada penelitian ini informasi tentang prosedur mencuci tangan, memakai masker, social distancing, kesiapan sekolah menghadapi new normal diberikan melalui video berdurasi antara 5-7 menit. Hal ini sejalan dengan Rahmawati, Sudargo, \& Paramastri, (2007) yang menyatakan bahwa audio visual merupakan alat bantu yang paling tepat dalam pendidikan kesehatan sebab pengetahuan yang ada pada seseorang diterima melalui indera, $75 \%$ sampai $87 \%$ dari pengetahuan manusia diperoleh atau disalurkan melalui indera penglihatan dan $13 \%$ melalui indera dengar.

Sesuai dengan fase-fase yang dapat terjadi setelah seseorang mendapatkan pendidikan kesehatan, tujuan dan hasil yang diharapkan adalah peningkatan pengetahuan, perubahan kebiasaan, dan proses menyadarkan orang lain dalam berperilaku (Kriswanto, 2012). Dalam teori Benyamin Bloom (1956) dalam Kriswanto (2012) menyatakan bahwa pengetahuan atau kognitif merupakan domain penting yang membentuk tindakan seseorang. Oleh karena itu pengetahuan seseorang tentang suatu objek tertentu sangat penting terhadap perubahan atau kemampuan seseorang dalam melakukan suatu tindakan yang merupakan proses kompleks.

WHO dalam Notoatmodjo (2012) juga mengungkapkan bahwa seseorang berperilaku tertentu disebabkan oleh pemikiran dan perasaan dalam bentuk pengetahuan, persepsi, sikap, kepercayaan, dan penilaian-penilaian seseorang terhadap objek. Perilaku yang didasari oleh pengetahuan lebih baik dari perilaku yang tidak didasari pengetahuan. Dalam hal ini penggunaan audiovisual sebagai media pendidikan kesehatan terhadap pencegahan penyebaran COVID-19 dan persiapan sekolah menghadapi new normal dapat meningkatkan pengetahuan guru dalam keenam subvariabel yang diajarkan. Dengan demikian keberhasilan SDM sekolah dalam mempersiapkan kondisi menghadapi new normal nantinya tertuama saat pertemuan tatap muka di sekolah dimulai, maka diharapkan semua guru dapat menyebarkan dan memberikan contoh yang tepat kepada siswanya dalam berperilaku sehat dan tepat. Berdasarkan hasil penelitian, pendidikan kesehatan dengan penggunaan media audivisual berpengaruh terhadap tingkat pengetahuan guru dalam pencegahan penyebaran COVID-19 dan persiapan sekolah menghadapi new normal di SMP Islam berbasis boarding school.

Sekolah berbasis boarding shool (berasrama) menyelenggarakan pendidikan dalam bentuk full day activity. Dalam arti 24 jam siswa dan guru berinteraksi di lingkungan sekolah. Hal ini tentu berresiko untuk terjadinya kontak terus menerus antar siswa, antar guru dan siswa, yang memungkinkan penyebaran virus corona ini terjadi. Untuk mencegahnya sangat penting baik guru maupun siswa untuk memahami tindakan pencegahan yang tepat. Melalui media 
pendidikan virtual yang telah diberikan kepada guru, diharapkan guru dapat menjadi role model yang benar kepada siswa, sehingga sekolah berasrama tidak menjadi kluster penyebaran covid19 yang baru. Hasil penelitian ini menunjukkan bahwa pendidikan yang tepat, akan menghasilkan perilaku yang tepat dan diharapkan.

\section{SIMPULAN}

Berdasarkan hasil penelitian tentang pengaruh media audiovisual dalam edukasi pencegahan penyebaran COVID-19 dan kesiapan sekolah dalam menghadapi masa transisi new normal pada guru-guru di SMP Islam berbasis boarding school menunjukkan bahwa pemberian edukasi dengan menggunakan media audiovisual berpengaruh pada tingkat pengetahuan responden. Hasil penelitian menunjukan bahwa pengetahuan responden secara keseluruhan sebelum perlakuan terbagi menjadi 41,67\% baik, 50\% cukup dan 8,33\% kurang, setelah perlakuan data menunjukan $100 \%$ pengetahuan responden menjadi baik. Dengan demikian dapat disimpulkan $\mathrm{H} 0$ ditolak dan Ha diterima atau hipotesis penelitian diterima.

\section{SARAN}

Saran-saran yang diberikan antara lain:

1. Guru dapat memperhatikan media edukasi, baik cetak ataupun audiovisual yang telah disediakan untuk meningkatkan pengetahuan tentang pencegahan penyebaran COVID19 dan persiapan menghadapai masa transisi new normal sehingga kesiapan sekolah jika tatap muka dilakukan nantinya dapat lebih baik

2. Puskesmas, Dinas Kesehatan dapat memanfaatkan hasil penelitian sebagai masukan untuk meningkatkan pendidikan kesehatan kepada seluruh seolah-sekolah berbasis boarding school terutama dalam pemberian edukasi melalui media audiovisual berkaitan dengan penyediaan sarana dan prasarana.

3. Bagi institusi pendidikan dapat menjadikan hasil penelitian sebagai bahan literatur serta kajian pustaka bagi penelitian-penelitian yang akan datang terutama penelitian yang berhubungan dengan media audiovisual, pencegahan penyebaran COVID-19 dan persiapan isntitusi pendidikan di semua strata yang berbasis asrama dalam menghadapi masa new normal dan pengetahuan pelakunya. Diharapkan penelitian selanjutnya dilakukan denngan studi komparatif dengan media kelompok kontrol sehingga perbandingan antara dua kelompok tampak lebih jelas atau dilakukan dengan studi longitudinal.

\section{REFERENCE}

Abdulamir, A. S., \& Hafidh, R. R. (2020). The possible immunological pathways for the variable immunopathogenesis of COVID - 19 infections among healthy adults, elderly and children. Electronic Journal of General Medicine, 17(4), 1-4. https://doi.org/10.29333/ejgm/7850

Budiman, \& Riyanto, A. (2014). Kapita Selekta Kuesioner Pengetahuan dan Sikap dalam Penelitian Kesehatan. Kapita Selekta Kuesioner Pengetahuan dan Sikap dalam Penelitian Kesehatan.

Compton, S., Sarraf-Yazdi, S., Rustandy, F., \& Kumar Radha Krishna, L. (2020). Medical students' preference for returning to the clinical setting during the COVID-19 pandemic. Medical Education, 0-3. https://doi.org/10.1111/medu.14268 
Covino, M., De Matteis, G., Santoro, M., Sabia, L., Simeoni, B., Candelli, M., ... Franceschi, F. (2020). Clinical characteristics and prognostic factors in COVID-19 patients aged $\geq 80$ years. Geriatrics \& Gerontology International, (March), 1-5. https://doi.org/10.1111/ggi.13960

Direktorat Jendral Pencegahan dan Pengendalian Penyakit. 2020. Pedoman Pencegahan dan Pengendalian Corona Virus Disease (Covid-19). Kementrian Kesehatan Republik Indonesia. Jakarta.

Ega, R. (2020). COVID-19 dalam Perspektif One Health Approach dan Law Enforcement. COVID-19 Dalam Perspektif One Health Approach Dan Law Enforcement.

Hirooka, Y. (2020). Covid-19. Journal of Medical Ultrasonics, 47(2), 339. https://doi.org/10.1007/s10396-020-01014-w

Kemenkes. (2020). Panduan Pelayanan Kesehatan Balita Pada Masa Tanggap Darurat COVID19. Kementrian Kesehatan RI, 1-30.

Kementrian Kesehatan RI. (2020). Dashboard Data Kasus COVID-19 di Indonesia. 6 Sepmber 2020. Diperoleh dari https://www.kemkes.go.id/ article/view/20031900002/Dashboard-Data-Kasus-COVID-19-di- Indonesia.html.

Kementrian Kesehtan RI. 2020. Situasi Terkini Perkembangan Coronavirus Disease (COVID-19) 6 Juli 2020 [Internet]. Diperoleh dari https://covid19.kemkes.go.id/situasi-infeksi-emerging/info-corona- virus/ situasiterkini-perkembangan-coronavirus-disease-covid-19-6-juli- 2020/\#. XwOYICgzbDc.

Keputusan Menteri Kesehatan Republik Indonesia Nomor HK.01/Menkes/413/2020. Pedoman Pencegahan dan Pengendalian Corona Virus Disease 2019 (Covid-19). 13 Juli 2020. Kementrian Kesehatan Republik Indonesia. Jakarta.

Li, G., Fan, Y., Lai, Y., Han, T., Li, Z., Zhou, P., ... Wu, J. (2020). Coronavirus infections and immune responses. Journal of Medical Virology, 92(4), 424-432. https://doi.org/10.1002/jmv.25685

Notoatmodjo, S. (2012). Rancangan Eksperimen Semu. In Metodologi Penelitian Kesehatan.

Notoatmodjo, S. (2014). Metodologi Penelitian Kesehatan (Revisi Vet). Jakarta: Rineka Cipta.

Özdemir, Ö. (2020). Coronavirus Disease 2019 (COVID-19): Diagnosis and Management (narrative review). Erciyes Medical Journal, 42(3). https://doi.org/10.14744/etd.2020.99836

Parwanto, M. (2020). Virus Corona (2019-nCoV) penyebab COVID-19. Jurnal Biomedika Dan Kesehatan. https://doi.org/10.18051/jbiomedkes.2020.v3.1-2

Puspasari, R. (2020). Pemerintah Waspada Dampak Pandemi Covid-19 Terhadap Ekonomi Indonesia. Kementerian Keuangan Republik Indonesia, (April), 17-21. Retrieved from https://www.kemenkeu.go.id/apbnkita/ 
Rothan, H. A., \& Byrareddy, S. N. (2020). The epidemiology and pathogenesis of coronavirus disease (COVID-19) outbreak. Journal of Autoimmunity, 109(February), 102433. https://doi.org/10.1016/j.jaut.2020.102433

Salzberger, B., Glück, T., \& Ehrenstein, B. (2020). Successful containment of COVID-19: the WHO-Report on the COVID-19 outbreak in China. Infection, 48(2), 151-153. https://doi.org/10.1007/s15010-020-01409-4

Shereen, M. A., Khan, S., Kazmi, A., Bashir, N., \& Siddique, R. (2020). COVID-19 infection: Origin, transmission, and characteristics of human coronaviruses. Journal of Advanced Research, 24, 91-98. https://doi.org/10.1016/j.jare.2020.03.005

Suni, N. S. P. (2020). Kesiapsiagaan Indonesia Menghadapi Potensi Penyebaran Corona. Pusat PenelitianBadan Keahlian DPR RI, XII(3), 14-18. Retrieved from https://berkas.dpr.go.id/puslit/files/info_singkat/Info Singkat-XII-3-I-P3DI-Februari2020-1957.pdf

Tay, M. Z., Poh, C. M., Rénia, L., MacAry, P. A., \& Ng, L. F. P. (2020). The trinity of COVID19: immunity, inflammation and intervention. Nature Reviews Immunology. https://doi.org/10.1038/s41577-020-0311-8

Tim Kerja Kementerian Dalam Negeri. (2013). Pedoman Umum Menghadapi Pandemi Covid19 Bagi Pemerintah Daerah: Pencegahan, Pengendalian, Diagnosis dan Manajemen. Journal of Chemical Information and Modeling, 53(9), 1689-1699. https://doi.org/10.1017/CBO9781107415324.004

Valerisha, A., \& Putra, M. A. (2020). Pandemi Global COVID-19 dan Problematika NegaraBangsa: Transparansi Data Sebagai Vaksin Socio-digital ? Pandemei Virus Covid-19. Retrieved from https://doi.org/10.26593/jihi.v0i0.3871.131-137

WHO. (2020). Coronavirus disease (COVID-19) pandemic. 